\title{
SHEAR STRENGTH IN FRICTION WELDED JOINT OF POPLAR WOOD IMPREGNATED WITH COPPER-BASED WOOD PRESERVATIVE
}

\author{
Mustafa Zor ${ }^{1}$ \\ https://orcid.org/0000-0002-2115-8339 \\ Ahmet Can ${ }^{2, \$}$ \\ https://orcid.org/0000-0001-5926-6039
}

\begin{abstract}
Environmentally friendly processes are of great interest and considerably needed due to the worldwide problem of pollution. Linear vibration welding of timber structural elements provides new opportunities to potentially achieve structural joints. Mechanically induced vibrational wood fusion welding is shown to be due mostly to the melting and flowing of some amorphous, cells-interconnecting polymer material in the structure of wood, mainly lignin, but also hemicelluloses. In this study, poplar (Populus euramericana) samples were impregnated with alkaline copper quat (ACQ) in order to enhance welding performance. Chemical changes of the impregnated and welded specimens were characterized by FT-IR techniques. A decrease in the proportion of unoxidized phenolic groups in the ligninwas observed by FT-IR and the decreased joint strength observed is impregnated wood. After impregnation, shear strength decreased by $37 \%$ to $54 \%$. The X-ray CT-scanning results revealed that the average density of the poplar wood $\left(368 \mathrm{~kg} / \mathrm{m}^{3}\right)$ increased to $710 \mathrm{~kg} / \mathrm{m}^{3}$ by welding.
\end{abstract}

Keywords: CT-scanning, FT-IR, impregnation, poplar, strength, wood density, wood welding.

\section{INTRODUCTION}

Water-based impregnating agents have been used in the wood protection industry for many years. Over the past 80 years, copper/chromium/arsenic (CCA) impregnation has been used worldwide. However, due to its negative impact on the environment and human health, restrictions on its use have been introduced. With the prohibition of CCA, the use of copper-containing impregnants such as copper azole (CA) and alkali copper quat (ACQ) has become widespread (Zhang et al. 2009).

Various methods are used in the combination of outdoor wood materials, including the commonly used approach of joining with traditional glues. The compatibility of impregnating agents with glues is another important factor affecting adhesion. The type of impregnation agent, the method of application, the amount of retention and surface interaction all affect the adhesion resistance (Vick and Christiansen 1993). The interaction of the glues used in the joining of the wood with the impregnating agents affects the end-use performance. For this purpose, several researchers have stated that the impregnation process decreases the adhesion resistance (Örs et al. 2004, Özçifçi 2006, Gardner et al. 2015, Kesik et al. 2016). 
Wood welding is a mechanical friction process that allows two pieces of wood to be joined together by fusion of the surfaces in contact and without the use of adhesive or other additives (Pizzi et al. 2003, Navi and Sandberg 2011). This friction-welding technique has been widely used for the joining of metal and thermoplastic-based materials. Industrial applications are rare for wood.

While the friction-welding technique is well established for wood materials (Pizzi 1982a, Pizzi 1982b, Pizzi et al. 2004), the present study aims to develop this technique for impregnated wood. In the literature, no studies have been found regarding impregnated welded poplar wood joints. In this study, the effects of ACQ impregnation applied at different concentrations on poplar wood produced by linear friction welding were investigated.

\section{MATERIALS AND METHODS}

\section{Material}

Populus euramericana (Poplar) wood samples (density $370 \mathrm{~kg} / \mathrm{m}^{3}$, moisture content $12 \%$ ) obtained from an industrial plant in Turkey. Test and control samples were prepared from sapwood blocks with dimensions of $20 \mathrm{~mm} \times 20 \mathrm{~mm} \times 200 \mathrm{~mm}$ (height $\mathrm{x}$ width $\mathrm{x}$ longitudinal). Selected specimens were knot-free, normally-grown wood material. The wood had no deficiencies and was without reaction, decay, insect or, fungal attack.

\section{Impregnation process of wood}

Wood samples were treated witheither $1 \%, 3 \%$ and $5 \%$ aqueous solutions of ACQ at $650 \mathrm{~mm}-\mathrm{Hg}$ vacuum for $30 \mathrm{~min}$. and a pressure of $0,5 \mathrm{MPa}$ for $60 \mathrm{~min}$. at room temperature. After treatment, specimens were reweighed to determine the ACQ retention. All treated specimens were then reconditioned at $20^{\circ} \mathrm{C} \pm 2^{\circ} \mathrm{C}$ and 65 $\% \pm 5 \%$ RH for 2 weeks, according to ASTM D1413 (1976).

Forty samples were prepared in total: 10 welded control samples and 30 welded samples impregnated with the selected concentrations of ACQ (alkaline copper quat). Before the experiment, the test samples were dried until they were stable at $20^{\circ} \mathrm{C} \pm 2{ }^{\circ} \mathrm{C}, 60 \% \pm 5 \%$ relative humidity and $12 \%$ moisture gradient in climate room. After the impregnation process, the samples were subjected to the welding process at the same moisture gradient.

The retention content for each treatment was calculated as follows (Equation 1):

$$
\text { Retention }=\frac{G \times C \times 10}{V}
$$

Where $G$ is the difference between sample weight after impregnation and sample weight before impregnation $(\mathrm{kg}), \mathrm{C}$ is the concentration $(\%)$, and $\mathrm{V}$ is the sample volume $\left(\mathrm{m}^{3}\right)$.

\section{Welding process of impregnated wood sample}

Forty specimens with a dimension of $200 \mathrm{~mm} \times 20 \mathrm{~mm} \times 20 \mathrm{~mm}(\mathrm{~L} \times \mathrm{R} \times \mathrm{T})$ were cut from the prepared impregnated poplar wood and welded together two by two in a linear-vibration welding machine (LVW 2061 Mecasonic) as shown in Figure 1. Five samples were used for each group. Welding machine settings for the preparation of welded specimens are shown in Table 1. 
Table 1: Welding-machine setting for the preparation of specimens.

\begin{tabular}{|l|c|c|}
\hline \multicolumn{1}{|c|}{ Parameter } & Units & Value \\
\hline Welding pressure (WP1 and WP2) & $(\mathrm{MPa})$ & 1,3 or 1,8 \\
\hline Welding time (WT1 and WT2) & $(\mathrm{s})$ & 2,5 or 3,0 \\
\hline Welding displacement (WD) & $(\mathrm{mm})$ & 2 \\
\hline Frequency & $(\mathrm{Hz})$ & 150 \\
\hline Holding pressure (H.P) & $(\mathrm{MPa})$ & 2 \\
\hline Holding time (H.T) & $(\mathrm{s})$ & 10 \\
\hline
\end{tabular}

\section{Shear strength}

Specimens composed of two pieces of Scots pine (Pinus sylvestris L.) each of dimensions $200 \mathrm{~mm} \times 20$ $\mathrm{mm} \times 20 \mathrm{~mm}$ were welded together to form a bonded specimen of dimensions $200 \mathrm{~mm} \times 20 \mathrm{~mm} \times 40 \mathrm{~mm}$ by a vibration movement of one wood surface against another. The samples were welded in the longitudinal wood grain direction. The specimens were cut according to the method described in European standard EN 302-1 (2013) for bonded wood joints with a welded overlap of $1 \mathrm{~cm}$ along the length of the joint and $2 \mathrm{~cm}$ width. The strengths of the joints were measured using an Instron universal testing machine at a rate of $2 \mathrm{~mm} / \mathrm{min}$ (Figure 1).

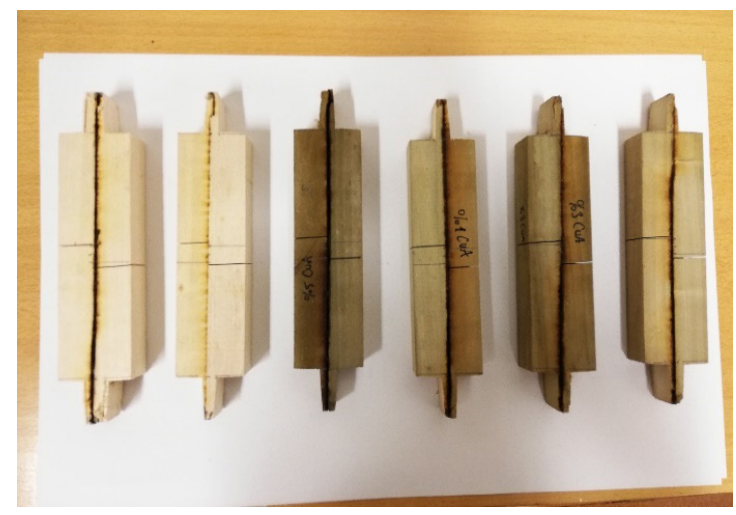

Figure 1: Shear strength test samples.

\section{CT-scanning study and image processing}

The welded poplar samples were studied by computed tomography (CT) scanning in a medical CT scanner (SIEMENS Emotion Duo medical X-ray CT-scanner) (Figure 2). 


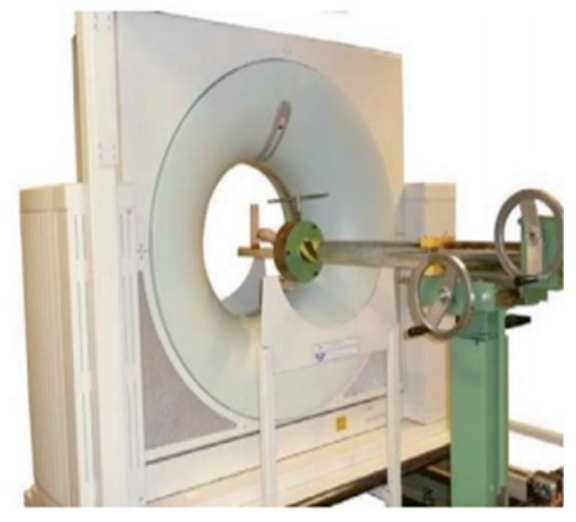

Figure 2: CT- scanner.

\section{Surface characterization by FT-IR}

The surface chemical composition of the welded poplar wood specimens were characterized before and after UV exposure using an attenuated total reflection (ATR) mode by Perkin Elmer, FT-IR Spectrometer Frontier and the wavenumber was set in the range from $4000 \mathrm{~cm}^{-1}$ to $600 \mathrm{~cm}^{-1}$.

\section{RESULTS AND DISCUSSION}

\section{Retention and shear tests}

When the impregnation concentration increased, the amount of retention increased. The highest retention was found $38,45\left(\mathrm{~kg} / \mathrm{m}^{3}\right)$ in 5\% ACQ (Table2).

Shear strength tests were carried out to understand the effects of different concentrations of ACQ on welded bonds as seen in Table 2, in welded poplar wood impregnated at different concentrations, the shear resistance values of welded wood decreased as the concentration increased. The fiber failure percentage of all specimens was reached by $100 \%$.

As for welded poplar wood after impregnation, the highest shear strength was found in the control sample $(7,59 \mathrm{MPa})$, whereas the lowest was found in 5\% ACQ impregnated (3,42 MPa). Higher shear strength values were obtained in $1 \%$ ACQ among impregnated wood materials that were impregnated. The impregnation material could prevent the creation of sufficient association between the bonding surfaces (welded line), causing the decrease of bonding strength.

Uysal (2006) conducted a study to determine the effects of wood pretreatment on the bonding strength of wood materials. Beech (Fagus orientalis Lipsky), Scots pine (Pinus sylvestris L.), oak (Quercus petreae Liebl.) and chestnut (Castanea sativa Mill.) were impregnated with Tanalith-C, creosote and Protim-WR 230 paraffin by full-cell methods according to ASTM D1413 (1976). After impregnation, shear strength tests were performed for samples bonded with PVAc, D-VTKA, and Pattex fast. The highest shear strength was obtained for the non-impregnated (control) and PVAc glued oak (5,328 MPa) and the lowest shear strength was obtained for chestnut glued with Protim-WR 230 paraffin and Pattex fast $(0,169 \mathrm{MPa})$. The impregnation process negatively affected the adhesive bonding strength. 
Table 2: Retention and Shear strength of poplar wood.

\begin{tabular}{|c|c|c|}
\hline & Retention $\left(\mathrm{kg} / \mathrm{m}^{3}\right)$ & Shear strength $(\mathrm{MPa})$ \\
\hline Control & - & $7,59^{\mathrm{a}}(0,18)$ \\
\hline $1 \%$ ACQ & $7,63^{\mathrm{c}}(0,25)$ & $4,73^{\mathrm{b}}(0,12)$ \\
\hline $3 \%$ ACQ & $23,70^{\mathrm{b}}(1,62)$ & $4,42^{\mathrm{b}}(0,92)$ \\
\hline $5 \%$ ACQ & $38,45^{\mathrm{a}}(2,13)$ & $3,42^{\mathrm{c}}(0,05)$ \\
\hline
\end{tabular}

In parentheses standard deviation; a,b,c indicate Duncan's homogeneity groups in the column. The fact that the letters are different shows that the variations take place in different groups.

Copper-containing impregnants react with wood compounds by the theory of ion exchange with wood. The majority of copper reacts with lignin, one of the wood components. This copper is absorbed by ion exchange by lignin acids and by hemicellulose uronic acids (Pizzi 1982a, Pizzi 1982b). Absorption of Cu by lignin causes a decrease in lignin peaks in wood (Figure 4). As is known, the welding technique works by friction and the temperature-induced increase at the interface leads to softening of the intercellular lignin, which then bonds the wood fibres. Fibres get detached, partially "ground" and the welded interphase is then formed. When friction is stopped, pressure is still applied until the solidification-compaction of the joint. Densification of the welded material and nearby zones are correlated with these chemical and anatomical changes (Gfeller et al. 2003). Therefore, the Tension-Shear strength values of all impregnated samples decreased.

\section{CT-scanning image}

The average wood density of the poplar samples was about $368 \mathrm{~kg} / \mathrm{m}^{3}$ while the maximum wood density in the welded bond was much higher at about $710 \mathrm{~kg} / \mathrm{m}^{3}$ (Figure 3). It has been demonstrated with X-ray computed tomography (CT) scanning that the amount of densification is increased with the welding process and thus creates tighter bonds. CT scanning is seen as a versatile research method for studying weld-merged trees. Faster and more realistic results can be learned in a non-destructive way with this method.

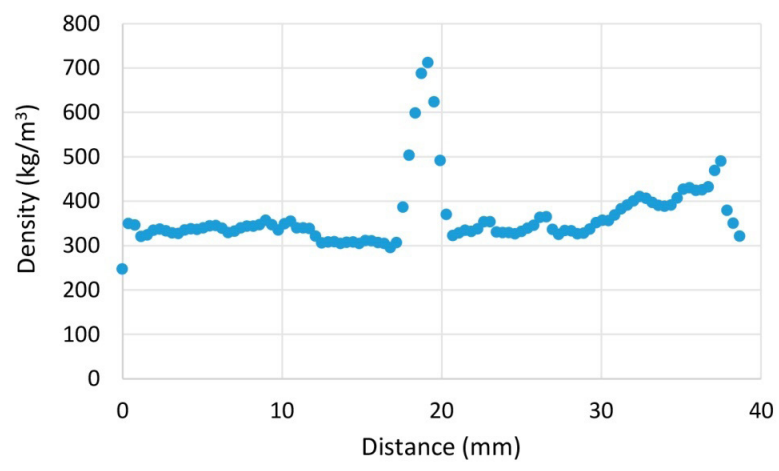

Figure 3: Measured density value of the welded poplar wood.

\section{FT-IR results}

FTIR spectroscopy was adopted to evaluate the adhesion surface chemistry changes of samples of welded impregnated poplar wood after shear test. The FTIR spectra of various welded impregnated poplar wood after shear test are shown in Figure 4. 


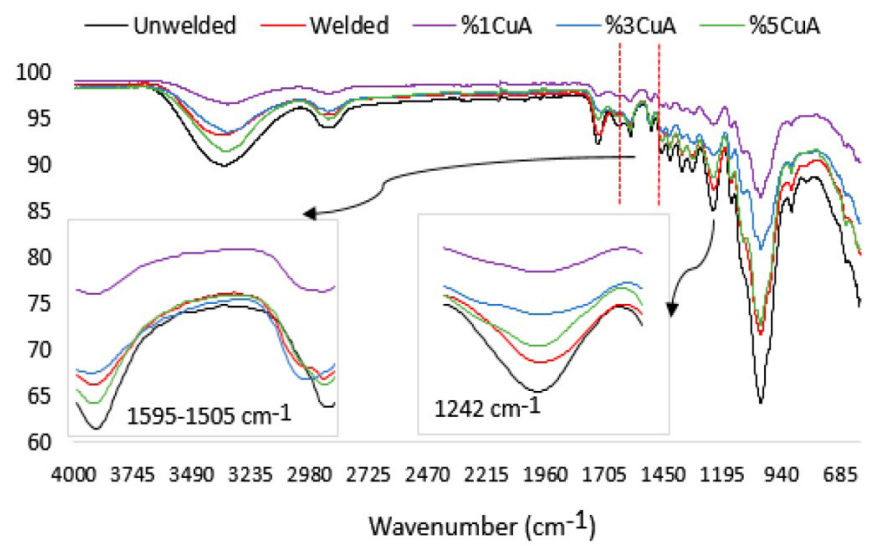

Figure 4: FTIR spectra of welded and control wood.

The FTIR analysis of the impregnated welded poplar wood samples was carried out in the range of 4000 $\mathrm{cm}^{-1}$ to $600 \mathrm{~cm}^{-1}$. It can be seen that the intensity of the peak at $3326 \mathrm{~cm}^{-1}(-\mathrm{OH})$ was clearly enhanced in the unwelded, control sample, which was mainly due to the reaction of the maleic group with the hydroxylgroup on a wood filler. The intensity of the peak at $1242 \mathrm{~cm}^{-1}$ band shows the $-\mathrm{CH}_{2}$ role in cellulose and different cellulose groups. Figure 4 shows marked differences mainly in the $1242 \mathrm{~cm}^{-1}$ band indicating a greater proportion of $\mathrm{C}-\mathrm{O}-\mathrm{C}$ linkages that are formed at $150 \mathrm{~Hz}$. The intensity of the peak at $1595 \mathrm{~cm}^{-1}$ band $\mathrm{C}=\mathrm{O}$ linked aryl ketones are associated with unbound $\mathrm{C}=\mathrm{C}$ and the water band. The bands at $1595 \mathrm{~cm}^{-1}$ and $1505 \mathrm{~cm}^{-1}$ also show more evident modifications of the aromatic rings of lignin in the case of $150 \mathrm{~Hz}$ welding frequency. The increase in unoxidized phenolic groups, observed by FT-IR, contributes to interfacial adhesion in the joint and thus to the greater strength of the joint welded at $150 \mathrm{~Hz}$, as it has been observed (Mansouri et al. 2009, Omrani et al. 2009). The marked decrease in quinone proportion explains the absence of a dark welded interphase at the joint line, which is obtained at $150 \mathrm{~Hz}$ welding frequency. The weldline is then colorless.

It is seen that as the impregnation concentration increased, the proportion of modified lignin decreased. Additionally, reductions in lignin ratio were observed with the welded procedure. In the sample impregnated with a concentration of 5\% ACQ in the band belonging to $1242 \mathrm{~cm}^{-1}$, there was an increase in density due to internal bonding resistance in wood by bonding with lignin based on $1 \%$ to $3 \%$ ACQ concentration. The welding process of wood to wood is based on the melting and flow of polymer material, mainly lignin, as well as hemicelluloses, which connect the amorphous cells in the wood structure (Pizzi et al. 2004).

\section{CONCLUSIONS}

The results of this study can contribute to the technological developments of applications of linear wood welding. Further analysis of the water and thermal resistance of joint and strength-after-aging tests is necessary to extend these technological developments. The impregnation material could prevent the creation of a sufficient association between the bonding (weld line), causing a decrease in bonding strength. Welded poplar shows higher shear resistance than welded impregnated poplar wood; this can be explained by the poor bonding of lignin in the wood with the impregnating agent. In shear strength values, shear resistance decreased as impregnation concentration increased according to the control sample. According to the results of FTIR, it is seen that there are increases in carbohydrate peaks around $1000 \mathrm{~cm}^{-1}$ of the samples impregnated at $5 \%$ concentration. In the wood sample impregnated at the same concentration, the increase in density was observed due to sufficient binding with lignin at $1242 \mathrm{~cm}^{-1}$ bonds. The density of the weld line was increased $90 \%$ by welding. 


\section{ACKNOWLEDGEMENTS}

The authors thank Birger Marklund for the sample preparations, Dr. Mojgan Vaziri for laboratory support, and Dr. Jose Couceiro for CT analysis. We gratefully acknowledge the Scientific and Technological Research Council of Turkey (TUBITAK-2219/BIDEB, 2019) for the scholarship of the visiting researcher Dr. Mustafa ZOR to do this post-doc study at the Luleå University of Technology, Skellefteå, SWEDEN.

\section{REFERENCES}

ASTM. 1976. Standard test methods of testing wood preservatives by laboratory soil block cultures. ASTM D1413-76. 1976. ASTM International: West Conshohocken, PA, USA.

EN. European Committee for standardization. 2013. Adhesives for load-bearing timber structures - test methods - part 1: determination of longitudinal tensile shear strength. EN 302-1.2013. European Committee for standardization: Brussels, Belgium.

Gardner, D. J.; Blumentritt, M.; Wang, L.; Yildirim, N. 2014. Adhesion theories in wood adhesive bonding. Reviews of Adhesion and Adhesives 2(2): 127-172. https://doi.org/10.7569/RAA.2014.097304

Gfeller, B.; Zanetti, M.; Properzi, M.; Pizzi, A.; Pichelin, F.; Lehmann, M.; Delmotte, L. 2003. Wood bonding by vibrational welding. Journal of Adhesion Science and Technology 17(11): 1573-1589. https://doi.org/10.1163/156856103769207419

Kesik, H.İ.; Keskin, H.; Temel, F.; Öztürk, Y. 2016. Bonding Strength and Surface Roughness Properties of Wood Materials Impregnated with Vacsol Aqua. Kastamonu Üniversitesi Orman Fakültesi Dergisi 16(1): 181-189. http://dergipark.ulakbim.gov.tr/kastorman/article/view/5000167402/5000167059

Mansouri, H.R.; Omrani, P.; Pizzi, A. 2009. Improving the water resistance of linear vibration-welded wood joints. Journal of Adhesion Science and Technology 23(1): 63-70. https://doi.org/10.1163/15685610 $8 X 335595$

Navi, P.; Sandberg, D. 2011. Thermo-hydro-mechanical wood processing. EPFL Press: New York. USA. ISBN: 978-2-940222-41-1, 280 pp. https://doi.org/10.1201/b10143

Omrani, P.; Pizzi, A.; Mansouri, H.R.; Leban, J.M.; Delmotte, L. 2009. Physico-chemical causes of the extent of water resistance of linearly welded wood joints. Journal of Adhesion Science and Technology 23(6): 827-837. https://doi.org/10.1163/156856108X396345

Örs, Y.; Atar, M.; Keske, H. 2004. Bonding strength of some adhesives in wood materials impregnated with Imersol-Aqua. International Journal of Adhesion and Adhesives 24(4):287-294. https://doi.org/10.1016/j.ijadhadh.2003.10.007

Özçifçi, A. 2006. Effects of Boron Compounds on the Bonding Strength of PF \& MF adhesives to impregnated wood materials. Journal of Adhesion Science and Technology 20(10): 1147-1153. https://doi.org/10.1163/156856106777890590

Pizzi, A. 1982a. The Chemistry and Kinetic Behavior of Cu-Cr-As Wood Preservatives. II. Fixation of $\mathrm{Cu} / \mathrm{Cr}$ system on wood. Journal of Polymer Science: Polymer Chemistry Edition 20(3): 704-724. https://onlinelibrary.wiley.com/doi/abs/10.1002/pol.1982.170200311

Pizzi, A. 1982b. The Chemistry and Kinetic Behavior of Cu-Cr-As Wood Preservatives. IV. Fixation of CCA to Wood. Journal of Polymer Science: Polymer Chemistry Edition 20(3): 739-764. https://doi.org/10.1002/pol.1982.170200313

Pizzi, A.; Properzi, M.; Leban, J.M.; Zanetti, M.; Pichelin, F. 2003. Mechanically induced wood welding. Maderas-Cienc Tecnol 5(2): 101-106. http://dx.doi.org/10.4067/S0718-221X2003000200001 
Pizzi, A.; Leban, J.M.; Kanazawa, F.; Properzi, M.; Pichelin, F. 2004. Wood dowel bonding by high-speed rotation welding. Journal of Adhesion Science and Technology 18(11): 1263-1278. https://doi.org/10.1163/1568561041588192

Uysal, B. 2006. Influence of pretreatment on shear strength of various wood species. Journal of Applied Polymer Science 100(1): 245-252. https://doi.org/10.1002/app.23030

Vick, C.B.; Christiansen, A.W. 1993. Cure of phenol-formaldehyde adhesive in the presence of CCAtreated wood by differential scanning calorimetry. Wood and Fiber Science 25(1): 77-86. https://wfs.swst.org/ index.php/wfs/article/view/1080/1080

Zhang, J.; Kamdem, D.P.; Temiz, A. 2009. Weathering of copper-amine treated wood. Applied Surface Science 256(3): 842-846. https://doi.org/10.1016/j.apsusc.2009.08.071 